\title{
Recent drugs and vaccine candidates to tackle COVID-19
}

\author{
Ehsan GHARIB MOMBENI ${ }^{1, \infty}$, Mahshad YOUSEFI' ${ }^{2}$, Saeid CHEKANI-AZAR ${ }^{3}$, Mohamed Samy ABOUSENNA ${ }^{4}$, \\ Kosar ARMIN ${ }^{2}$, Fatemeh SHAVANDI ${ }^{2}$, Elham EMAMI ${ }^{5}$ and Yadollah BAHRAMI ${ }^{6}$ \\ ${ }^{1} \mathrm{PhD}$, Department of Pathobiology, Shahid Chamran University of Ahvaz, Iran \\ ${ }^{2} \mathrm{MD}$, Hamadan University of Medical Sciences, Hamadan, Iran \\ ${ }^{3} \mathrm{PhD}$, Faculty of Veterinary Medicine, Animal Physiology, Atatürk University, Turkey \\ ${ }^{4} \mathrm{PhD}$ of Virology, Central Laboratory for Evaluation of Veterinary Biologics, Cairo, Egypt \\ ${ }^{5} \mathrm{PhD}$, Assistant prof., Department of Pediatric, Shahrekord University of Medical Science, Shahrekord, Iran \\ ${ }^{6} \mathrm{PhD}$ of Animal Biotechnology, Young Researchers Elite Club, Isfahan (Khorasgan) Branch, Islamic Azad University, Isfahan, Iran \\ Corresponding author's Email: E-Gharibmombeni@stu.scu.ac.ir; (D) ORCiD: 0000-0002-7211-2592
}

\section{ABSTRACT}

Introduction. The global devastating pandemic coronavirus disease 2019 (COVID19) is a worldwide multisystemic infection caused by the novel severe acute respiratory syndrome coronavirus 2 (SARS-CoV-2), which has emerged as a menace to the global public health and countries economy. There is a crucial necessity for the suggestion of effective drugs to eliminate the virus outbreak. Several candidate drugs with existing emerging evidence try to offer a pharmacological strategy that may inhibit infection in COVID-19 patients. By, October 2020, scientists have nominated some reliable and safe types of coronavirus vaccines like Pfizer, Moderna, AstraZeneca, CureVac, CoronaVac, etc. that are effective and showed $95 \%$ to $90 \%$ protection, respectively. Aim. This review highlights important clinical and in vitro studies, uses of potent antiviral drugs and most recent vaccines against COVID-19 disease.

Review Article
PII: S225199392000009-10
Rec. O2 September 2020
Rev. 18 November 2020
Pub. 25 November 2020
Keywords
Actemra, Antiviral medicines,
ARCoV, AstraZeneca,
ChulaCov19, CoronaVac,
COVID-19, CureVac, CytoSorb,
Ivermectin, Moderna,
Oleandrin, Pfizer, Remdesivir,
Ritonavir, Vaccines.

\section{INTRODUCTION}

Novel coronavirus (2019-nCoV) likes other coronaviruses belong to the coronaviridae family. Coronaviruses (CoVs) belong to the genus Coronavirus in the Coronaviridae family [1]. The CoVs are enveloped with a crown-like appearance with 120-160 $\mathrm{nm}$ in diameter, single-stranded RNA viruses between $27 \mathrm{~kb}$ and $31.5 \mathrm{~kb}$ with positive polarity, which the largest among known RNA viruses $[2,3]$. Members of the subfamily Coronavirinae are comprised of four genera. The genus Alphacoronavirus contains human and many animal viruses. The genus Betacoronavirus includes the Severe Acute Respiratory Syndrome-related (SARS-related) coronavirus, Middle Eastern Respiratory Syndrome (MERS) coronavirus, together with a number of human and animal coronaviruses. The genus Gammacoronavirus contains viruses of cetaceans (whales) and birds, and the genus Deltacoronavirus contains viruses isolated from pigs and birds. It seems that alpha- and beta-coronaviruses apparently originate from mammals, in particular from bats. The gamma- and delta-viruses originate from pigs and birds. Although alpha-coronaviruses cause a mild infection, apparently the beta-coronaviruses cause severe disease and fatalities in humans $[4,5]$.

On 31 December 2019, a number of patients with signs of pneumonia and without any specified etiology were reported in Wuhan, Hubei Province China. On 9 January 2020, China Centers for Disease Control and Prevention (CDC) confirmed that the cause of the outbreak is a novel coronavirus. In addition, it reported that based on phylogeny it belongs to the SARS-CoV clade [6]. By December 27, 2020, there has been over 80 million people infected and 1,761,749 deaths (Centre for Systems Science and Engineering. COVID-19 dashboard, 2020; Available from: https://coronavirus.jhu.edu/map.html). The major response to the coronavirus disease 2019 (COVID-19; previously 2019-nCoV) outbreak has been largely limited to monitoring/containment around the world. Meanwhile, there are many scientists looking for an effective solution to eliminating the COVID-19. In the following, there are some valid recent vaccines and effective medicines to tackle the novel coronavirus. 
Routinely, the approbation of an effective vaccine requires years of research and in vivo and in vitro examination before reaching the countries. Vaccine investigation procedures began in January 2020 with the deciphering of the SARS-CoV-2 genome. The first vaccine safety trials in humans started in March, and in October 2020, 10 reached the final stages of testing. However, a few vaccines have succeeded in stimulating the immune system to produce effective antibodies against the virus. By, October 2020, researchers tested 48 vaccines in clinical trials on humans, and at least 89 preclinical vaccines were under active investigation in animals. However, scientists have nominated some reliable types of vaccines effective on coronavirus this year [7].

1. Moderna vaccine. Moderna vaccine (produced by the collaboration of the National Institute of Allergy and Infectious Diseases (NIAID) and US biotech company) is based on messenger RNA mRNA-1273) encodes the spike 2 protein (S-2P) antigen, consisting of the SARS-CoV-2 glycoprotein with a transmembrane anchor and an intact S1-S2 cleavage site. S-2P is stabilized in its prefusion conformation by two consecutive proline substitutions at amino acid positions 986 and 987, at the top of the central helix in the S2 subunit [8], which triggers the body's immune system by producing viral spikes and spike protein fragments in the patient cells and on the cells surface, where the immune system could recognize, when a vaccinated cell dies, the cell debris will contain many spike proteins and protein fragments, the antigen-presenting cell will recognize it, on the other hand the $\mathrm{T}$ helper cells will detect the spike protein fragments on the cell surface which are essential to initiate the cellular and humoral immunity pathways to combat the SARS-CoV-2 infection. At the beginning of developing the vaccine, they reported the vaccine protects non-human primates (monkeys) against the SARSCoV-2. In March, the company put the first COVID-19 vaccine into human trials, which had successful results. The vaccine testing began on July 27. The US biotech company Moderna after a trial enrolled 30,000 participants included white, non-white, black, and Latina with a wide range of age (over and under 65 years old) around the United States (89 sites) reported its trial showed 94.5\% effectiveness [7, 9] and trial-limiting safety concerns were identified [10].

2. Pfizer vaccine. The German company BioNTech collaborates with Pfizer, which is based in New York, and the Chinese drugmaker Fosun Pharma to produce mRNA vaccine (BNT162b2) that encodes a prefusion stabilized, membrane-anchored SARS-CoV-2 full-length spike protein [11]. After a trial in May 2020, they found that the vaccine (BNT162b2) caused volunteers to produce antibodies against SARS-CoV-2, as well as T cells against the virus. They found that the vaccine had not any side effects, such as fevers and fatigue. On July 27, the companies designed a trial with more than 30,000 volunteers in Argentina, Brazil, Germany, and the United States [7, 9]. The Pfizer company announced that the vaccine was more than $90 \%$ effective [12]. Comparable with Moderna's vaccine, Pfizer and BioNTech's is an mRNA-based vaccine, both BNT and mRNA-1273 require booster doses in order to ensure high neutralizing antibody titer and (presumably) long term immunogenicity. Despite the necessity of a second dose, the antibody response against the SARS-CoV-2 receptor-binding domain (RBD) of both vaccines showed significantly higher titers compared to patients who have recovered from COVID-19 $[13,14]$ both vaccines require to be kept in a deep freeze condition. Consequently, the Pfizer vaccine will have to be frozen to minus 80 degrees Celsius (minus 112 degrees Fahrenheit) until the injection time [7, 9]., while Moderna's vaccine could be stored and shipped at minus 20 degrees Celsius (stable up to six months) , anticipated to persist stably at a refrigerator temperature $\left(2^{\circ}\right.$ to $8^{\circ} \mathrm{C}=36^{\circ}$ to $\left.46^{\circ} \mathrm{F}\right)$ for 30 days and at a room temperature remain stable for up to 12 hours (https://www.cdc.gov/vaccines/covid-19/info-byproduct/moderna/index.html ; https://investors.modernatx.com/news-releases/news-release-details/modernaannounces-longer-shelf-life-its-covid-19-vaccine).

3. CureVac. CureVac is a biopharmaceutical company, based in the Netherlands and headquartered in Tübingen, Germany. In March, CureVac began its research on an mRNA vaccine. The company reported promising responses in mice. CureVac announced that the company would make the vaccine by the end of 2020 and hoped to gain human usage approval in $2021[7,15,16]$.

4. The US company Arcturus Therapeutics and Duke-NUS Medical School in Singapore produced a selfreplicating $\mathrm{mRNA}$-based vaccine which leads to greater production of viral proteins [7].

5. Imperial College London researchers have produced an RNA-based vaccine that has a self-amplifying method, which boosts the production of a viral protein to trigger the immune system. On June 15, they began the trials; the researchers announced the vaccine might be ready for human usage by the end of 2020 [7].

6. ARCoV. In June, Chinese Military Medical researchers, Suzhou Abogen Biosciences and Walvax Biotechnology announced that they began a trial on an mRNA-based vaccine (ARCoV) [7, 17]. 
7. ChulaCov19. On Sept. 29, Thailand's Chulalongkorn University announced that they are developing an mRNA-based vaccine (ChulaCov19) [7].

8. Entos is a Canadian pharmaceutical company that created a DNA vaccine (Covigenix VAX-OOl) for the coronavirus. Entos instead of spike protein gene chose the gene for nucleocapsid, a protein that sits inside the virus's envelope $[7,18]$.

9. Sanofi is a French pharmaceutical company that corporate with Translate Bio. The company announced an mRNA vaccine that produces an acceptable level of antibody in mice and monkeys trials [7, 19-21].

10. On June 30, the Japanese biotechnology company AnGes with corporate by Osaka University and Takara Bio started a trial on a DNA-based vaccine. The vaccine was created based on a consensus SARS-CoV-2 spike glycoprotein sequence with an N-terminal IgE leader, added to enhance expression in target cells and increase immunogenicity. The company is planning to produce the vaccine by the end of $2020[7,22,23]$.

11. Zydus. In July, Zydus Cadila an Indian pharmaceutical company began testing a DNA-based skin-patch vaccine [7].

12. The US company Inovio produced a DNA-based vaccine that applied to the skin with electric pulses from a hand-held device. They announced that there are not any side-effects. On Sept. 28, the F.D.A. hold the research due to needing the delivery device [7, 24].

13. In June, The Korean company Genexine began producing a DNA-based vaccine [7, 25].

14. CoronaVac. CoronaVac (Sinovac Life Sciences, Beijing, China) is an inactivated vaccine against SARSCoV-2 which was developed from a SARS-CoV-2 strain isolated from a patient in the Jinyintan Hospital, Wuhan. The virus was propagated on Vero cell line, and it was inactivated with $\beta$-propiolactone, the prepared antigen then adsorbed onto an adjuvant (aluminum hydroxide) [26] .CoronaVac induced humoral immune responses against SARS-CoV-2, which supported the approval of emergency use of CoronaVac in China and other different countries., there is no clear evidence that the vaccine induced T-cell responses [27].

15. AstraZeneca. It is recombinant vaccine (ChAdOxl) which was developed at Oxford University, The ChAdOxl nCoV-19 vaccine (AZD1222) consists of a replication-deficient chimpanzee adenoviral vector ChAdOxl, containing the SARS-CoV-2 structural surface glycoprotein antigen (spike protein; nCoV-19) gene that expresses a full S protein it was found that the recombinant vaccine ChAdOxl has accepted safety profile well tolerated and immunogenic $[28,29]$.

\section{LIST OF DRUGS EFFECTIVE ON CORONAVIRUS}

\section{Actemra (tocilizumab), a Roche's anti-inflammatory drug}

In numerous patients, COVID-19 infection is associated with a cytokine storm [30-35]. In this case, coronavirus patients will encounter serious lung complications and it can also lead to death and in recovered cases, the excessive immune responses lead to long-term lung damage and fibrosis [36, 37]. Nevertheless, there is no applicable specific antiviral treatment, and or designing potent antiviral drugs against the COVID-19 will take years to develop [38-40], use of anti-inflammatory drugs like Actemra can be more effective, to tackle the COVID-19 outbreak. Perrone et al. [41] reported that Tocilizumab reduced lethality rate at 30 days compared with the null hypothesis, without significant toxicity, which supports the use of Tocilizumab among patients not requiring mechanical ventilation and independent of the effect of corticosteroids.

China approved the use of Roche's anti-inflammatory drug Tocilizumab (trade names: Actemra, RoActemra) - an interleukin-6 inhibitor [42] - to treat patients infected with the new coronavirus who have developed serious lung damage and also have elevated levels of IL-6 - a biomarker for inflammation and a high-level immune response- in the blood that is associated with a higher mortality rate in people with communityacquired pneumonia (http://www.pmlive.com/pharma_news/china_backs_use_of_roches_actemra_for_coronavirus_1328014). Actemra has known as interleukin-6 inhibitor can interrupt Cytokine Release Syndrome and regulate systemic inflammatory response and complication of some diseases or infections [43].

\section{Favipiravir (T-705), a broad-spectrum inhibitor of viral RNA polymerase [44] and ribavirin}

Favipiravir and ribavirin are representative of nucleoside analogs. Nucleoside analogs as a broad-spectrum antiviral have several mechanisms of effects in vitro, including lethal mutagenesis, non-specific the nascent DNA chain termination, and inhibiting the biosynthesis of nucleotides. Wang et al. [45] proved that favipiravir combined with oseltamivir is more effective than oseltamivir alone in treating severe influenza (RNA virus). Coronaviruses are RNA viruses. However, they express exonuclease in non-structural protein 14 (nsp14-ExoN) 
and are conserved throughout the coronavirus family, which has an RNA proofreading function [46]. Smith et al. [47] reported that ribavirin in an in vitro experiment has a low effect on coronavirus. In 2017 Furuta et al. [44] reported an effective inhibitor of viral RNA polymerase (Favipiravir, T-705; 6-fluoro-3-hydroxy-2-pyrazine carboxamide) as an anti-viral medicine that selectively and potently inhibits the RNA-dependent RNA polymerase (RdRp) of RNA viruses. It was discovered through a screening chemical library for anti-viral activity against the influenza virus by Toyama Chemical Co., Ltd. Favipiravir undergoes a phosphoribosylation in the hostess cell to be an active form, favipiravir-RTP (favipiravir ribofuranosyl-5'-triphosphate), which is recognized as a substrate by RdRp, and inhibits the RNA polymerase activity. Since the catalytic domain of RdRp is preserved among numerous types of RNA viruses, this mechanism of action underpins a broader spectrum of anti-viral activities of favipiravir. Favipiravir is effective against a wide range of types and subtypes of influenza viruses, including to anti-influenza drugs resistant strains. Noticeably, favipiravir has potent anti-viral activities against other RNA viruses, likewise; arenaviruses, bunyaviruses, and filoviruses, all of which are known to cause fatal hemorrhagic fever. These unique anti-viral profiles will make favipiravir a potentially promising drug for specifically incurable RNA viral infections.

\section{Ivermectin, an inhibitor of the replication of SARS-CoV-2 in vitro}

Ivermectin is an effective inhibitor of the SARS-CoV-2 clinical isolate Australia/VICo1/2020. Ivermectin has been licensed for more than 20 years for the treatment of parasitic infections in human and animals. Considering that this well-tolerated drug, Mastrangelo et al. [48] in 2102, reported new prospects for an old widely used anti-helminthic medicine, Ivermectin, as a potent inhibitor of flavivirus replication specifically targeting NS3 (non-structural protein 3) helicase domain activity. This drug not only displayed a high-predicted binding affinity towards the modeled NS3 ssRNA binding pocket but also inhibited the NS3 helicase activity of different flaviviruses in vitro at sub-micromoles concentrations. Most importantly, ivermectin proved to be a selective inhibitor of the replication of several flaviviruses in cell culture, such as Japanese encephalitis (JEV), tick-borne encephalitis viruses (TBEV), and dengue viruses (DENV) (sub-micromolar $\mathrm{EC}_{50}$ values) [49], and a highly potent inhibitor of yellow fever virus (YFV) replication (sub-nanomolar $\mathrm{EC}_{50}$ values) [49]. Caly et al. [50] in 2020 also reported Ivermectin as an FDA-approved anti-parasitic, is an inhibitor of the causative virus (SARS-CoV-2), with a single addition to Vero-hSLAM cells 2 hours post-infection with SARS-CoV-2 able to effect $\sim 5000$-fold reduction in viral RNA at $48 \mathrm{~h}$. Therefore, this drug warrants further investigation for possible benefits in humans, especially against the virus COVID-19.

\section{Remdesivir (GS-5734)}

Remdesivir is an adenosine analog, which interferes with the activity of viral RNA-dependent RNApolymerases (RdRp) and results in premature termination, which is effective against a wide range of RNA viruses (including SARS/MERS-CoV) [51, 52]. The chloroquine is used against malarial, autoimmune disease, and recently introduced as a potential broad-spectrum antiviral medicine. The function of chloroquine is to increase endosomal $\mathrm{pH}$, which requires virus/cell fusion, as well as it interferes with the glycosylation of cellular receptors of SARS-CoV [53-55]. The results of in vitro cell with submicromolar EC50 values confirmed that remdesivir has potent antiviral activity in vitro against human coronaviruses (HCoV-OC43 and HCoV-229E) and coronaviruses related to zoonotic bat-CoV [56]. Jordan et al. (2018) reported that GS-5734 triphosphate might not able to excised by the proofreading activity of nspl4 due to lack of immediate chain termination, as observed in human respiratory syncytial virus (RSV) polymerase [57, 58].

\section{Ibavirin, penciclovir, nitazoxanide, nafamostat, chloroquine}

Wang et al. [45] evaluated five antiviral medications including ribavirin, penciclovir, nitazoxanide, nafamostat, chloroquine, and two broad-spectrum antiviral medicines remdesivir (GS5734) and favipiravir (T705) against a clinical isolate of 2019- $\mathrm{nCoV}$ in vitro. Hence, their evaluation was based on measuring the effects of these agents on the cytotoxicity, virus yield, and infection rates of 2019-nCoVs in the Vero E6 cells, which had infected with nCoV2019BetaCoV/Wuhan/WIVo4/2019. They reported that high concentrations of three nucleoside analogs including ribavirin, penciclovir, and favipiravir were reduced the viral infection. Nafamostat, which has anti-membrane fusion activity, is a potent inhibitor against MERS-Cov and COVID-19. The nitazoxanide, which is an antiprotozoal medicine, has antiviral activity against animals and humans coronaviruses including COVID-19. Remdesivir and chloroquine potently blocked virus infection. Furthermore, chloroquine is a cheap and safe medicine that has an immune-modulating activity, which may improve its anti- 
viral efficacy in the in vivo. In addition, oral administration of chloroquine can be prepared an efficient dosage in the lungs $[59,60]$.

\section{ACE2}

According to research, while ACE2 protects the lungs from injury, it is a key receptor for severe acute respiratory syndrome coronavirus (SARS-CoV). There is a report that injecting SARS-CoV spike into mice decreased ACE2 expression levels, thereby worsening lung injury [61,62]. Recent studies stated that SARS-CoV2 spike protein recognized human ACE2 even higher binding affinity than spike from SARS-CoV. ACE2 is in alveolar epithelial type 2 cells which produce surfactant that prevents alveoli from collapse, heart, kidney, blood vessels, and intestine that can explain the multi-organ dysfunction observed in patients. Scientists have created artificial ACE-2 proteins which might be able to act as decoys, luring the coronavirus away from vulnerable cells. Soluble recombinant human ACE2 (srhACE2) is a drug that has undergone phase 1 testing in healthy volunteers and phase 2 testing in some patients with acute respiratory distress syndrome (ARDS). Studies showed that this clinical-grade human ACE2 molecule can inhibit SARS-CoV-2 infection and reduce viral load and block entry of SARS-CoV-2 infection in host cells but the inhibition is not complete, although clearly dosedependent [63-65]. Due to this fact, there might be a co-receptor or other mechanisms by which viruses can enter cells.

\section{Oleandrin}

Oleandrin extract derived from the Nerium oleander plant has shown inhibitory activity against several viruses such as HIV-1 and HTLV-1 [66]. Oleandrin is known as a toxic cardiac glycoside found in oleander, a poisonous plant, but research stated that it has a strong potential against envelope viruses. Hutchison et al. [67], has studied oleandrin's potential in Southern Methodist University against leukemia virus type-1 so that inhibits human t-cell leukemia virus type-1 (HTLV-1) infectivity and env-dependent virological synapse formation. The results of use of this botanical glycoside demonstrated antiviral activity against enveloped viruses; therefore it can be an intriguing idea for researchers against the COVID-19 outbreak. Given that SARSCoV-2 is also an enveloped virus, oleandrin could be effective in reducing viral load both when administered before and after infection. It can inhibit the $\mathrm{Na}, \mathrm{K}$-ATPase by blockade of ATP binding site. Another enzyme that requiring ATP is ACE2 which is an important receptor for SARS-CoV-2. An unpublished study has shown that sublingual administration of oleandrin caused more safe and rapid plasma concentration of oleandrin than oral administration because of the absence of the first passed effect of the liver. Oleandrin crosses the blood-brain barrier where can causes induction of some factors. According to poorly understood neurological manifestation presenting in some COVID-19 patients, oleandrin may have some benefit in preventing virus-associated neurological disease. Oleandrin can also make an anti-inflammatory response that prevents hyperinflammatory responses to SARS-CoV-2. It can cause heart arrhythmias, making the plant dangerous to ingest. Scientists worry about the safety of oleandrin as a treatment for the coronavirus, given the toxicity of the plant.

\section{MK-4482}

MK-4482 previously known as EIDD-2801, originally designed to fight the flu, is an orally bioavailable NHC prodrug that has a wide range of antiviral activity against SARS-CoV, MERS-CoV, and SARS-CoV-2 in primary HAE (human airway epithelial) cells [68]. The drug showed promising results against the new coronavirus in studies this spring in cells and on animals. It improves pulmonary function and virus titer drop and reduced the bodyweight loss. When NHC is incorporated during RNA synthesis, increase the mutation rates and leading to an error by inducing an error rate of replication that surpasses the error threshold allowed to sustain a virus population.

\section{Convalescent/Recovery plasma}

Plasma products of recovered patients are safe to use and can reduce the mortality of patients with severe influenza A and SARS-CoV infection and it is safe to use [69]. While Van Griensven et al. [70] with a nonrandomized comparative study on Ebola virus infection showed that compared with patients in the treatment group, after infusion of up to $500 \mathrm{ml}$ of plasma, has not seen any significant improvement in survival rate [70]. The efficacy and safety of convalescent plasma for patients, which infected with COVID-19, should be evaluated by considering titers of plasma neutralizing antibodies in the donor rehabilitate patients. 


\section{Monoclonal antibody}

Mulangu et al. [71] conducted a prospective randomized controlled study on Ebola patients in the Democratic Republic of Congo. They reported that monoclonal antibody REGN-EB3 and monoclonal antibody 114 (MAb114) significantly reduce the mortality rate [71].

\section{Lopinavir/Ritonavir}

Lopinavir is a protease inhibitor (PI), which derived from ritonavir (antiretroviral medication). Coadministration of it with ritonavir showed potent and selective inhibitor activity against HIV-1 protease, which is an essential enzyme for the production of mature, infective viruses. Lopinavir with a modest antiviral activity against SARS-CoV-2 acts also against the viral 3CL protease [58]. Ritonavir increases drug bioavailability and its use together with Lopinavir and the immunomodulator interferon beta-lb is known for the treatment of MERS (ClinicalTrials.gov number, NCT02845843) [72]. Prescription of lopinavir/ritonavir provides a sufficient and durable suppression of viral load uphold the CD4+ cell (cluster of differentiation 4) counts. In addition, reported that this regimen was more effective than nelfinavir in HIV-1-infected patients. The most common associated side effects were gastrointestinal disturbances, asthenia, headache, and skin rash [73]. Chan et al. [74] reported that lopinavir/ritonavir inhibited coronavirus replication to a certain extent in vitro experiments. Furthermore, they showed that the lopinavir/ritonavir and interferon- $\beta 1 \mathrm{~b}$ in the treatment of marmoset infected with MERS$\mathrm{CoV}$ as an animal model was convenient [74]. They reported that during the SARS epidemic in 2003, Hong Kong, China. 41 patients with SARS treated with the combination of lopinavir/ritonavir and ribavirin significantly showed acute respiratory distress syndrome or death lower than 111 SARS patients treated with ribavirin [75]. Therefore, Lopinavir/ritonavir should be regarded as a candidate for an effective medicine in the management of COVID-19 infection. Beginning on January 18, 2020 and at a single hospital in Wuhan, China, Cao et al. [76] conducted an open-label randomized trial on 199 adult patients with COVID-19 infection to investigate the effectiveness of lopinavir-ritonavir for SARS-CoV-2. The patients also had pneumonia and oxygen saturation of $<94 \%$ along with standard care alone (group 1 ) is compared to those receive $400 \mathrm{mg}-100 \mathrm{mg}$ lopinavir-ritonavir orally and twice daily for a period of 14 days. They did not observe any significant difference between both groups however those who received lopinavir-ritonavir had lower 28-day mortality (19\% vs. 25\%, not significant). There are also no significant changes in coronavirus RNA concentrations obtained from throat swabs of both groups' patients. Efficacy of chloroquine (CQ) has been tested in vivo using a mouse-adapted SARS-CoV (MA15) challenge to evaluate anti-viral efficacy which led to the hypothesis that the in vitro effects of $C Q$ on MA15 and other coronaviruses was affecting entry and lipid membrane alterations, while in vivo the main effect was anti-inflammatory rather than anti-viral [77, 78]. This demonstrated that while there are features of infection that are altered by $C Q$ treatment, it did not diminish viral replication in this model.

\section{Hydroxychloroquine (HCQ) and/or chloroquine (CQ)}

HCQ and CQ seem to demonstrate anti-viral properties in simple Vero cell assays. However, effects are not seen in life-like or more complex infection models such as organ-on-chips, which use human respiratory cells [78]. Based on some consistent findings observed in four different laboratories and also some evidence from related researches, Funnell et al. [78] reported no significant therapeutic benefit of HCQ in SARS-CoV-2 infection model studies on non-human primates like hamsters. Thus, available data do not support the broad use of HCQ to treat COVID-19 disease.

\section{Dexamethasone}

There are many guidelines for the treatment of patients with COVID-19 stating that glucocorticoids are either not recommended or contraindicated [79]; but in China, Zhao et al. [80] have a consensus on the use of corticosteroid in severe cases of 2019-nCoV pneumonia. Donnelly et al. [81] have identified the critical role of macrophage migration inhibitory factor (MIF) as inflammation-mediated lung injury in bronchoalveolar lavage fluids (BALF) from acute respiratory distress syndrome (ARDS) patients. The role of MIF as an inflammatory mediator and its complex with glucocorticoids is taken into consideration in recent and ongoing trials of glucocorticoids [82-88]. However, Fernandes et al. [82] stated that high doses of steroids may induce negative side effects due to the profound immunodepression and could counterbalance positive effects or could be even neutral or deleterious. Horby et al. [87] reported that glucocorticoids may regulate cytokine-mediated inflammation in the lung of COVID-19 patients and thereby reduce progression to respiratory failure and death. They stated significantly lower mortality at 28 days with a shorter duration of hospitalization in 10 days- 
dexamethasone groups in comparison to the usual care group. Duration of hospitalization has a direct link with the risk of progression to invasive mechanical ventilation. However, they did not find any benefit among patients who were not receiving respiratory support at randomization and the results were consistent with possible harm in the dexamethasone group.

\section{CytoSorb ${ }^{\circledR}$}

CytoSorb ${ }^{\circledR}$ filter/device is a non-pyrogenic, sterile, single-use device placed in a blood pump circuit and it is containing adsorbent polymer beads designed to remove cytokines, as blood passes through the device. Cytosorbents ${ }^{\circledR}$ cytokine filter as a potential treatment methodology is used for the reduction of the cytokine storm and its pro-inflammatory levels and is of particular relevance as a bridge for therapy in patients with acute stage of COVID-19 [89]. Clinical experience suggests COVID -19 patients require higher anticoagulation at the start of treatment to prevent circuit clots off [89-92]. Anticoagulation in this case should be heparin [93] because this device may remove other anticoagulants and antiplatelet agents. Although, CytoSorb ${ }^{\circledR}$ reduce circulating inflammatory mediatory the risks are a hemodynamic compromise, arrhythmia, blood loss, hypoalbuminemia, thrombosis, air embolism, infection, hemolysis, hypocalcemia, thrombocytopenia, allergic reaction to device materials, unintended removal of other blood substances, risk related to vascular access placement, risk related to anticoagulation [89, 90, 93].

\section{Interferon beta-1a}

Interferons are molecules that are naturally produced by our cells in response to viruses. They can rouse the immune system to attack the invaders under the control of the body's own tissues from any damage. The coronavirus appears to tamp down interferon so injecting synthetic interferons is now a standard treatment for a number of immune disorders [94, 95]. For example, Interferon $\beta$ 1a, Rebif ${ }^{\circledR}$ is prescribed for multiple sclerosis [95]. Interferon (IFN) $\beta$-1a has been reported as highly effective in inhibiting in vitro SARS-CoV-2 replication at clinically achievable concentration when administered after virus infection. In vitro observations revealed that IFN- $\beta$-1a effectively inhibits both infectious virus particles and viral RNA on treated cells, when compared to virus-positive infection control without toxicity at its highest tested concentration [96]. The drug $\mathrm{EC}_{50}$ evaluated at 48, 72, and 96 hours after infection is suggested to be easily accessed in the clinical setting to help address drug administration regimens in vivo [96].

\section{DECLARATIONS}

\section{Authors' contributions}

E.GharibMombeni, S.Chekani-Azar and M.Yousefi conceived the main review on drugs and vaccines and MS.Abousenna edited vaccines section, and K.Armin, F.Shavandi, E.Emami and Y.Bahrami performed review on some of drugs and S.Chekani-Azar and E.GharibMombeni edited the final version of manuscript.

\section{Conflict of interest}

The authors declare that there is no conflict of interest.

\section{REFERENCES}

1. MacLachlan NJ, Dubovi EJ. In: NJ MacLachlan, EJ Dubovi, eds. Book title: Fenner's Veterinary Virology. 5th ed. Cambridge, MA: Academic Press; p. 393- 413. ISBN: 978-0-12-375158-4. 2017.

2. Masters, Paul S. Book title: The molecular biology of coronaviruses. Advances in virus research, 66. 2006: p. 193-292. DOI: https://doi.org/10.1016/S0065-3527(06)66005-3.

3. Siddell SG. Book title: The coronaviridae. Springer, 1995: p. 1-10. ISBN 978-1-4899-1531-3.

4. De Groot RJ, Baker SC, Baric R, Enjuanes L, Gorbalenya A, Holmes KV, Perlman S, Poon L, Rottier PJ, Talbot PJ, Woo PC. Coronaviridae. Virus Taxonomy: ninth report of the International Committee on Taxonomy of Viruses. Secondary title: Elsevier Academic: London, United Kingdom; 2011:806-28. ISBN: 9780123846846.

5. Burrell CJ, Howard CR and Murphy FA. Chapter 31 - coronaviruses. In: Burrell CJ, Howard CRandMurphy FA, editors. Book title: Fenner and White's Medical Virology . London: Academic Press, 2017: p. 437-446. ISBN: 9780123751560.

6. World Health Organization. Coronavirus disease 2019 (COVID-19), Geneva: Situation Report 3.2020. https://apps.who.int/iris/bitstream/handle/10665/331780/nCoVsitrep2020-eng.pdf.

7. Corum J, Grady D, Wee S-LandZimmer C. Coronavirus vaccine tracker. The New York Times. 2020 ; 5. http://www.nomeofficinapolitica.it/wp-content/uploads/2020/10/Vaccini_NYT.pdf.

8. Wrapp D, Wang N, Corbett KS, Goldsmith JA, Hsieh C-L, et al. Cryo-em structure of the 2019-ncov spike in the prefusion conformation.

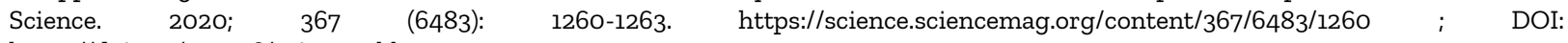
https://doi.org/10.1126/science.abb2507 
9. Mahase E. Covid-19: Moderna vaccine is nearly 95\% effective, trial involving high risk and elderly people shows. BMJ: British Medical Journal (Online). 2020; 371. DOI: http://dx.doi.org/10.1136/bmj.m4471.

10. Jackson LA, Anderson EJ, Rouphael NG, Roberts PC, Makhene M, et al. An mrna vaccine against sars-cov-2-preliminary report. New England Journal of $2020 . \quad$ Dedicine. https://doi.org/10.1056/NEJMoa2022483; https://www.nejm.org/doi/full/10.1056/NEJMoa2022483.

11. Polack FP, Thomas SJ, Kitchin N, Absalon J, Gurtman A, et al. Safety and efficacy of the bnt162b2 mrna covid-19 vaccine. New England Journal of Medicine. 2020. DOI: https://doi.org/10.1056/NEJMoa2034577; https://www.nejm.org/doi/full/10.1056/NEJMoa2034577.

12. Mahase E. Covid-19: Vaccine candidate may be more than 90\% effective, interim results indicate. BMJ. 2020; 371: m4347. Link Retrieved from journal https://www.bmj.com/content/bmj/371/bmj.m4347.full.pdf.10.1136/bmj.m4347

13. Anderson EJ, Rouphael NG, Widge AT, Jackson LA, Roberts PC, et al. Safety and immunogenicity of sars-cov-2 mrna-1273 vaccine in older adults. New England Journal of Medicine. 2020. DOI: http://dx.doi.org/10.1056/NEJMoa2028436; https://www.nejm.org/doi/full/10.1056/NEJMoa2028436.

14. Mulligan MJ, Lyke KE, Kitchin N, Absalon J, Gurtman A, et al. Phase i/ii study of covid-19 rna vaccine bnt162bl in adults. Nature. 2020; 586 (7830): 589-593. DOI: https://doi.org/10.1038/s41586-020-2639-4.

15. Cohen J. Vaccine designers take first shots at covid-19. Secondary title: American Association for the Advancement of Science; 2020. DOI: http://dx.doi.org/10.1126/science.368.6486.14; https://science.sciencemag.org/content/368/6486/14.

16. Zhang J, Zeng H, Gu J, Li H, Zheng L, et al. Progress and prospects on vaccine development against sars-cov-2. Vaccines. 202O; 8 (2): 153. DOI: https://doi.org/10.339o/vaccines8020153.

17. Baran I. Sars-cov-2 vaccine development strategies. Medical sciences and biotechnology book. 2020; 7:65.

18. Mertz L. One shot wonder: A vaccine against all coronaviruses. IEEE pulse. 2020; 11 (6): $2-5 . \quad$ DOI: https://doi.org/10.1109/MPULS.2020.3036198; https://ieeexplore.ieee.org/stamp/stamp.jsp?tp=\&arnumber=9293474.

19. Bertin P, Nera KandDelouvée S. Conspiracy beliefs, rejection of vaccination, and support for hydroxychloroquine: A conceptual replication-extension in the covid-19 pandemic context. Frontiers in psychology. 2020; 11: 2471. DOI: https://doi.org/10.3389/fpsyg.2020.565128.

20. Evenett SJ. Chinese whispers: Covid-19, global supply chains in essential goods, and public policy. Journal of International Business Policy. 2020; 3 (4): 408-429. DOI: https://doi.org/10.1057/s42214-020-00075-5.

21. Mucchielli L. Behind the french controversy over the medical treatment of covid-19: The role of the drug industry. Journal of Sociology. 2020: 1440783320936740. DOI: https://doi.org/10.1177/1440783320936740.

22. Shervani $Z$, Khan IandQazi UY. Sars-cov-2 delayed tokyo 2020 olympics: Very recent advances in covid-19 detection, treatment, and vaccine development useful conducting the games in 2021. Advances in Infectious Diseases. 2020; 10 (03): 56. DOI: https://doi.org/10.4236/aid.2020.103007; https://www.scirp.org/html/7-1950476_101321.htm.

23. Taxt AM, Grødeland G, Lind A, Müller F. Status of COVID-19 vaccine development. Tidsskrift for Den norske legeforening. 2020 Sep 23. DOI: https://doi.org/10.4045/tidsskr.20.0676; https://tidsskriftet.no/en/2020/og/kronikk/status-covid-19-vaccine-development.

24. Cohen J. New coronavirus threat galvanizes scientists. Secondary title: American Association for the Advancement of Science; 2020. DOI: https://doi.org/10.1126/science.367.6477.492; https://science.sciencemag.org/content/367/6477/492.

25. Dwipayana IDAP. Efforts in securing vaccine for covid-19 outbreak in indonesia. Health Notions. 2020; 4 (10): 313-317. DOI: https://doi.org/10.33846/hn41001; http://www.heanoti.com/index.php/hn/article/view/59o.

26. Xia $S$, Duan $K$, Zhang $Y$, Zhao $D$, Zhang $H$, et al. Effect of an inactivated vaccine against sars-cov-2 on safety and immunogenicity outcomes: Interim analysis of 2 randomized clinical trials. Jama. 2020; 324 (10): 951-960. DOI: http://dx.doi.org/10.1001/jama.2020.15543; https://jamanetwork.com/journals/jama/article-abstract/2769612.

27. Zhang Y, Zeng G, Pan H, Li C, Hu Y, et al. Safety, tolerability, and immunogenicity of an inactivated sars-cov-2 vaccine in healthy adults aged 18-59 years: A randomised, double-blind, placebo-controlled, phase 1/2 clinical trial. The Lancet Infectious Diseases. 2020. DOI: https://doi.org/10.1016/S1473-3099(20)30843-4.

28. van Doremalen N, Lambe T, Spencer A, Belij-Rammerstorfer S, Purushotham J, et al. ChAdOx1 nCoV-19 vaccination prevents SARSCoV-2 pneumonia in rhesus macaques. bioRxiv. 2020; https://www.ncbi.nlm.nih.gov/pmc/articles/PMC7241103/i https://dx.doi.org/10.1101\%2F2020.05.13.093195

29. Voysey M, Clemens SAC, Madhi SA, Weckx LY, Folegatti PM, et al. Safety and efficacy of the chadoxl ncov-19 vaccine (azd1222) against sars-cov-2: An interim analysis of four randomised controlled trials in brazil, south africa, and the uk. The Lancet. 2020. DOI: https://doi.org/10.1016/S0140-6736(20)32661-1.

30. Zumla A, Hui DS, Azhar EI, Memish ZAandMaeurer M. Reducing mortality from 2019-ncov: Host-directed therapies should be an option. The Lancet. 2020. DOI: https://doi.org/10.1016/So140-6736(20)30305-6.

31. Hui DSandZumla A. Severe acute respiratory syndrome: Historical, epidemiologic, and clinical features. Infectious Disease Clinics. 2019; 33 (4): 869-889. DOI: https://doi.org/10.1016/j.idc.2019.07.001.

32. Azhar EI, Hui DS, Memish ZA, Drosten CandZumla A. The middle east respiratory syndrome (mers). Infectious Disease Clinics. $2019 ; 33$ (4): 891-905. DOI: https://doi.org/10.1016/j.idc.2019.08.001.

33. Huang C, Wang Y, Li X, Ren L, Zhao J, et al. Clinical features of patients infected with 2019 novel coronavirus in wuhan, china. The Lancet. 2020. DOI: https://doi.org/10.1016/S0140-6736(20)30183-5.

34. Li G, Fan Y, Lai Y, Han T, Li Z, et al. Coronavirus infections and immune responses. Journal of Medical Virology. 202O. DOI: https://doi.org/10.1002/jmv.26517.

35. Channappanavar RandPerlman S. Pathogenic human coronavirus infections: Causes and consequences of cytokine storm and immunopathology. Secondary title: Springer; 2017. p. 529-539. DOI : https://doi.org/10.1007/s00281-017-0629-x; https://link.springer.com/article/10.1007/s00281-017-0629.

36. Batawi S, Tarazan N, Al-Raddadi R, Al Qasim E, Sindi A, et al. Quality of life reported by survivors after hospitalization for middle east respiratory syndrome (mers). Health and quality of life outcomes. 2019; 17 (1): 101. DOI: https://doi.org/10.1186/s12955-019-1165-2.

37. Ngai JC, Ko FW, Ng SS, TO KW, Tong M, et al. The long-term impact of severe acute respiratory syndrome on pulmonary function, exercise capacity and health status. Respirology. 2010; 15 (3): 543-550. DOI: https://doi.org/10.1111/j.1440-1843.2010.01720.x.

38. Zumla A, Chan JF, Azhar EI, Hui DSandYuen K-Y. Coronaviruses-drug discovery and therapeutic options. Nature reviews Drug discovery. 2016; 15 (5): 327. DOI: https://doi.org/10.1038/nrd.2015.37; https://www.nature.com/articles/nrd.2015.37.

39. Beigel JH, Nam HH, Adams PL, Krafft A, Ince WL, et al. Advances in respiratory virus therapeutics-a meeting report from the 6th isirv antiviral group conference. Antiviral research. 2019. DOI: https://doi.org/10.1016/j.antiviral.2019.04.006. 
40. Zumla A, Azhar EI, Arabi Y, Alotaibi B, Rao M, et al. Host-directed therapies for improving poor treatment outcomes associated with the middle east respiratory syndrome coronavirus infections. Secondary title: Elsevier; 2015 . DOI: https://doi.org/10.1016/j.ijid.2015.09.005.

41. Perrone F, Piccirillo MC, Ascierto PA, Salvarani C, Parrella R, et al. Tocilizumab for patients with covid-19 pneumonia. The single-arm tocivid-19 prospective trial. Journal of translational medicine. 2020; 18 (1): 1-11. DOI: https://doi.org/10.1186/s12967-020-02573-9.

42. Jones GandDing C. Tocilizumab: A review of its safety and efficacy in rheumatoid arthritis. Clinical medicine insights. Arthritis and musculoskeletal disorders. 2010; 3: 81-89. DOI: https://doi.org/10.4137/CMAMD.S4864; PMCID: PMC3018893 https://www.ncbi.nlm.nih.gov/pmc/articles/PMC3018893/

43. de Cáceres C, Martínez R, Bachiller P, Marín LandGarcía JM. The effect of tocilizumab on cytokine release syndrome in covid-19 patients. Pharmacological reports : PR. 2020; 72 (6): 1529-1537. DOI: https://doi.org/10.1007/s43440-020-00186-z; https://link.springer.com/article/10.1007/s43440-020-00186-z

44. Furuta Y, Komeno TandNakamura T. Favipiravir (t-705), a broad spectrum inhibitor of viral rna polymerase. Proceedings of the Japan Academy, Series B. 2017; 93 (7): 449-463. DOI: https://doi.org/10.2183/pjab.93.027.

45. Wang Y, Fan G, Salam A, Horby P, Hayden FG, et al. Comparative effectiveness of combined favipiravir and oseltamivir therapy versus oseltamivir monotherapy in critically ill patients with influenza virus infection. The Journal of infectious diseases. 2019. DOI: https://doi.org/10.1093/infdis/jiz656.

46. Minskaia E, Hertzig T, Gorbalenya AE, Campanacci V, Cambillau C, et al. Discovery of an rna virus $3^{\prime} \rightarrow 5^{\prime}$ exoribonuclease that is critically involved in coronavirus rna synthesis. Proceedings of the National Academy of Sciences. 2006; 103 (13): 5108-5113. DOI: https://doi.org/10.1073/pnas.0508200103.

47. Smith EC, Blanc H, Vignuzzi MandDenison MR. Coronaviruses lacking exoribonuclease activity are susceptible to lethal mutagenesis: Evidence for proofreading and potential therapeutics. PLoS pathogens. 2013; 9 (8). DOI: https://doi.org/10.1371/journal.ppat.1003565.

48. Mastrangelo E, Pezzullo M, De Burghgraeve T, Kaptein S, Pastorino B, et al. Ivermectin is a potent inhibitor of flavivirus replication specifically targeting ns3 helicase activity: New prospects for an old drug. Journal of Antimicrobial Chemotherapy. 2012; 67 (8): 18841894. DOI: https://doi.org/10.1093/jac/dks147.

49. Gould EA, and Solomon T. Pathogenic flaviviruses. The Lancet. 2008; 371 (9611): 500-509. DOI: https://doi.org/10.1016/Sol406736(08)60238-X.

50. Caly L, Druce JD, Catton MG, Jans DAandWagstaff KM. The fda-approved drug ivermectin inhibits the replication of sars-cov-2 in vitro. Antiviral Research. 2020. DOI: http://www.sciencedirect.com/science/article/pii/So166354220302011. https://doi.org/10.1016/j.antiviral.2020.104787

51. Warren TK, Jordan R, Lo MK, Ray AS, Mackman RL, et al. Therapeutic efficacy of the small molecule gs-5734 against ebola virus in rhesus monkeys. Nature. 2016; 531 (7594): 381-385. DOI: https://doi.org/10.1038/nature17180.

52. Sheahan T, Sims A, Graham R, Menachery V, Gralinski L, et al. Broad-spectrum antiviral gs-5734 inhibits both epidemic and zoonotic coronaviruses. Sci transl med 9: Eaal3653. Secondary title; 2017. DOI: https://doi.org/10.1126/scitranslmed.aal3653.

53. Savarino A, Di Trani L, Donatelli I, Cauda RandCassone A. New insights into the antiviral effects of chloroquine. The Lancet infectious diseases. 2006; 6 (2): 67-69. DOI: https://doi.org/10.1016/S1473-3099(06)70361-9.

54. Yan Y, Zou Z, Sun Y, Li X, Xu K-F, et al. Anti-malaria drug chloroquine is highly effective in treating avian influenza a h5nı virus infection in an animal model. Cell research. 2013; 23 (2): 300-302. DOI: https://doi.org/10.1038/cr.2012.165.

55. Vincent MJ, Bergeron E, Benjannet S, Erickson BR, Rollin PE, et al. Chloroquine is a potent inhibitor of sars coronavirus infection and spread. Virology journal. 2005; 2 (1): 69. DOI: https://doi.org/10.1186/1743-422X-2-69.

56. Brown AJ, Won JJ, Graham RL, Dinnon KH, Sims AC, et al. Broad spectrum antiviral remdesivir inhibits human endemic and zoonotic deltacoronaviruses with a highly divergent rna dependent rna polymerase. Antiviral Research. 2019 ; 169: 104541. http://www.sciencedirect.com/science/article/pii/So166354219300993; DOI: https://doi.org/10.1016/j.antiviral.2019.104541

57. Jordan PC, Stevens SKandDeval J. Nucleosides for the treatment of respiratory rna virus infections. Antiviral Chemistry and Chemotherapy. 2018; 26: 2040206618764483. DOI: https://doi.org/10.1177/2040206618764483.

58. Sheahan TP, Sims AC, Leist SR, Schäfer A, Won J, et al. Comparative therapeutic efficacy of remdesivir and combination lopinavir, ritonavir, and interferon beta against mers-cov. Nature Communications. 2020; 11 (1): 1-14. DOI: https://doi.org/10.1038/s41467-01913940-6.

59. Wang M, Cao R, Zhang L, Yang X, Liu J, et al. Remdesivir and chloroquine effectively inhibit the recently emerged novel coronavirus (2019-ncov) in vitro. Cell research. 2020; 30 (3): 269-271. DOI: https://doi.org/10.1038/s41422-020-0282-0.

6o. Mackenzie AH. Dose refinements in long-term therapy of rheumatoid arthritis with antimalarials. The American journal of medicine. 1983; 75 (1): 40-45. DOI: https://doi.org/10.1016/0002-9343(83)91269-X.

61. Monteil V, Kwon H, Prado P, Hagelkrüys A, Wimmer RA, et al. Inhibition of sars-cov-2 infections in engineered human tissues using clinical-grade soluble human ace2. Cell. 2020. DOI: https://doi.org/10.1016/j.cell.2020.04.004.

62. Dinnon KH, Leist SR, Schafer A, Edwards CE, Martinez DR, et al. A mouse-adapted sars-cov-2 model for the evaluation of covid-19 medical countermeasures. bioRxiv. 2020. DOI: https://doi.org/10.1038/s41586-020-2708-8.

63. Miao X, Luo Y, Huang X, Lee SM, Yuan Z, et al. A novel biparatopic hybrid antibody-ace2 fusion that blocks sars-cov-2 infection: Implications for therapy. Secondary title: Taylor \& Francis; 2020. p. 1804241. DOI: https://doi.org/10.1080/19420862.2020.1804241.

64. Souza PF, Lopes FE, Amaral JL, Freitas CDandOliveira JT. A molecular docking study revealed that synthetic peptides induced conformational changes in the structure of sars-cov-2 spike glycoprotein, disrupting the interaction with human ace 2 receptor. International journal of biological macromolecules. 2020; 164: 66-76. DOI: https://doi.org/10.1016/j.ijbiomac.2020.07.174.

65. Kalhor H, Sadeghi S, Abolhasani H, Kalhor RandRahimi H. Repurposing of the approved small molecule drugs in order to inhibit sarscov-2 s protein and human ace2 interaction through virtual screening approaches. Journal of Biomolecular Structure and Dynamics. 2020: 1-16. DOI: https://doi.org/10.1080/07391102.2020.1824816.

66. Plante KS, Plante JA, Fernandez D, Mirchandani D, Bopp N, et al. Prophylactic and therapeutic inhibition of in vitro sars-cov-2 replication by oleandrin. bioRxiv. 2020; DOI: https://doi.org/10.1101/2020.07.15.203489.

67. Hutchison T, Yapindi L, Malu A, Newman RA, Sastry KJ, et al. The botanical glycoside oleandrin inhibits human t-cell leukemia virus type-1 infectivity and env-dependent virological synapse formation. J Antivir Antiretrovir. 2019; 11 (3). DOI: https://doi.org/10.35248/1948-5964.19.11.184.

68. Sheahan TP, Sims AC, Zhou S, Graham RL, Pruijssers AJ, et al. An orally bioavailable broad-spectrum antiviral inhibits sars-cov-2 in human airway epithelial cell cultures and multiple coronaviruses in mice. Science Translational Medicine. 2020; 12 (541). DOI: https://doi.org/10.1126/scitranslmed.abb5883. 
69. Mair-Jenkins J, Saavedra-Campos M, Baillie JK, Cleary P, Khaw F-M, et al. The effectiveness of convalescent plasma and hyperimmune immunoglobulin for the treatment of severe acute respiratory infections of viral etiology: A systematic review and exploratory metaanalysis. The Journal of infectious diseases. 2015; 211 (1): 80-90. DOI: https://doi.org/10.1093/infdis/jiu396.

70. Van Griensven J, Edwards T, de Lamballerie X, Semple MG, Gallian P, et al. Evaluation of convalescent plasma for ebola virus disease in guinea. New England Journal of Medicine. 2016; 374 (1): 33-42. DOI: https://doi.org/10.1056/NEJMoal511812.

71. Mulangu S, Dodd LE, Davey Jr RT, Tshiani Mbaya O, Proschan M, et al. A randomized, controlled trial of ebola virus disease therapeutics. New England Journal of Medicine. 2019; 381 (24): 2293-2303. DOI: https://doi.org/10.1056/NEJMoalg10993.

72. Baden LR and Rubin EJ. Covid-19-the search for effective therapy. The New England Journal of Medicine; 2O2O. DOI: https://doi.org/10.1056/NEJMe2005477.

73. Cvetkovic RSandGoa KL. Lopinavir/ritonavir. Drugs. 2003; 63 (8): 769-802. DOI: https://doi.org/10.2165/00003495-200363080-00004.

74. Chan JF-W, Yao Y, Yeung M-L, Deng W, Bao L, et al. Treatment with lopinavir/ritonavir or interferon- $\beta$ lb improves outcome of merscov infection in a nonhuman primate model of common marmoset. The Journal of infectious diseases. 2015; 212 (12): 1904-1913. DOI: https://doi.org/10.1093/infdis/jiv392.

75. Chu C, Cheng V, Hung I, Wong M, Chan $\mathrm{K}$, et al. Role of lopinavir/ritonavir in the treatment of sars: Initial virological and clinical findings. Thorax. 2004; 59 (3): 252-256. DOI: https://doi.org/10.1136/thorax.2003.012658.

76. Cao B, Wang Y, Wen D, Liu W, Wang J, et al. A trial of lopinavir-ritonavir in adults hospitalized with severe covid-19. New England Journal of Medicine. 2020. DOI: https://doi.org/10.1056/NEJMoa2001282.

77. Weston S, Coleman CM, Sisk JM, Haupt R, Logue J, et al. Broad anti-coronaviral activity of fda approved drugs against sars-cov-2 in vitro and sars-cov in vivo. bioRxiv. 2020. DOI: https://doi.org/10.1101/2020.03.25.008482.

78. Funnell SGP, Dowling WE, Muñoz-Fontela C, Gsell PS, Ingber DE, et al. Emerging preclinical evidence does not support broad use of hydroxychloroquine in covid-19 patients. Nature Communications. 2020; 11 (1): 4253. DOI: https://doi.org/10.1038/s41467-020-17907-w.

79. Dagens A, Sigfrid L, Cai E, Lipworth S, Cheng V, et al. Scope, quality, and inclusivity of clinical guidelines produced early in the covid-19 pandemic: Rapid review. BMJ. 2020; 369: m1936. https://www.bmj.com/content/bmj/369/bmj.m1936.full.pdf.10.1136/bmj.m1936; DOI: https://doi.org/10.1136/bmj.m1936

80. Zhao JP, Hu Y, Du RH, Chen ZS, Jin Y, Zhou M, Zhang J, Qu JM, Cao B. Expert consensus on the use of corticosteroid in patients with 2019-nCoV pneumonia. Zhonghua jie he he hu xi za zhi=Chinese journal of tuberculosis and respiratory diseases. 2020; $43(3): 183-4$. DOI: https://doi.org/10.3760/cma.j.issn.1001-0939.2020.03.008.

81. Donnelly SC, Haslett C, Reid PT, Grant IS, Wallace WA, et al. Regulatory role for macrophage migration inhibitory factor in acute respiratory distress syndrome. Nature medicine. 1997; 3 (3): 320-323. DOI: https://doi.org/10.1038/nmo397-320.

82. Fernandes A, Zin WandRocco P. Corticosteroids in acute respiratory distress syndrome. Brazilian journal of medical and biological research. 2005; 38 (2): 147-159. DOI: https://doi.org/10.1590/So100-879X2005000200003.

83. Reddy $\mathrm{K}$, O'Kane CandMcAuley D. Corticosteroids in acute respiratory distress syndrome: A step forward, but more evidence is needed. The Lancet Respiratory Medicine. 2020; 8 (3): 220-222. DOI: https://doi.org/10.1016/S2213-2600(20)30048-5.

84. Tang BM, Craig JC, Eslick GD, Seppelt IandMcLean AS. Use of corticosteroids in acute lung injury and acute respiratory distress syndrome: A systematic review and meta-analysis. Critical care medicine. 2009; 37 (5): 1594-1603. DOI: https://doi.org/10.1097/CCM.obo13e31819fb507.

85. Arabi YM, Mandourah Y, Al-Hameed F, Sindi AA, Almekhlafi GA, et al. Corticosteroid therapy for critically ill patients with middle east respiratory syndrome. American journal of respiratory and critical care medicine. 2018; 197 (6): $757-767$. DOI: https://doi.org/10.1164/rccm.201706-1172OC.

86. De Benedictis FMandBush A. Corticosteroids in respiratory diseases in children. American journal of respiratory and critical care medicine. 2012; 185 (1): 12-23. DOI: https://doi.org/10.1164/rccm.201107-1174CI.

87. Horby P, Lim WS, Emberson JR, Mafham M, Bell JL, et al. Dexamethasone in hospitalized patients with covid-19-preliminary report. The New England journal of medicine. 2020. DOI: https://dx.doi.org/10.1056\%2FNEJMoa2021436.

88. Goodman RB, Pugin J, Lee J, SandMatthay MA. Cytokine-mediated inflammation in acute lung injury. Cytokine \& growth factor reviews. 2003; 14 (6): 523-535. DOI: https://doi.org/10.1016/S1359-6101(03)00059-5.

89. Rizvi S, Danic M, Silver MandLaBond V. Cytosorb filter: An adjunct for survival in the covid-19 patient in cytokine storm? A case report. Heart \& Lung. 2020. DOI: https://doi.org/10.1016/j.hrtlng.2020.09.007.

9o. Alharthy A, Faqihi F, Memish ZA, Balhamar A, Nasim N, et al. Continuous renal replacement therapy with the addition of cytosorb ${ }^{\circledR}$ cartridge in critically ill patients with covid-19 plus acute kidney injury: A case-series. Artificial Organs. 2020. DOI: https://doi.org/10.1111/aor.13864.

91. Rieder M, Wengenmayer T, Staudacher D, Duerschmied DandSupady A. Cytokine adsorption in patients with severe covid-19 pneumonia requiring extracorporeal membrane oxygenation. Critical Care. 2020; 24 (1): 1-2. DOI: https://doi.org/10.1186/s13054-02003130-y.

92. Supady A, Duerschmied D, Bode C, Rieder M, Lother A. Extracorporeal cytokine adsorption as an alternative to pharmacological inhibition of IL-6 in COVID-19. Critical Care. 2020 Dec;24(1):1-2. DOI: https://doi.org/10.1186/s13054-020-03238-1.

93. US Food and Drug Administration. CytoSorb ${ }^{\circledR} 300 \mathrm{~mL}$ Device Approved by FDA for Emergency Treatment of COVID-19. N (\%) or median (range). 2020. https://www.fda.gov/media/136866/download.

94. Monk PD, Marsden RJ, Tear VJ, Brookes J, Batten TN, et al. Safety and efficacy of inhaled nebulised interferon beta-la (sngool) for treatment of sars-cov-2 infection: A randomised, double-blind, placebo-controlled, phase 2 trial. The Lancet Respiratory Medicine. 2020. DOI: https://doi.org/10.1016/S2213-2600(20)30511-7.

95. Manfredonia F, Pasquali L, Dardano A, Iudice A, Murri L, et al. Review of the clinical evidence for interferon $\beta$ la (rebif ${ }^{8}$ ) in the treatment of multiple sclerosis. Neuropsychiatric disease and treatment. 2008; 4 (2): 321. DOI: https://doi.org/10.1093/infdis/jiaa350.

96. Clementi N, Ferrarese R, Criscuolo E, Diotti RA, Castelli M, et al. Interferon- $\beta$-la inhibition of severe acute respiratory syndromecoronavirus 2 in vitro when administered after virus infection. The Journal of infectious diseases. 2020; 222 (5): 722-725. DOI: https://doi.org/10.1093/infdis/jiaa350. 